\title{
MENCIPTAKAN SEKOLAH YANG BERKARAKTER
}

\author{
Fatkhul Mubin
}

fatkhulmubin90@gmail.com

\section{A. PENDAHULUAN}

Indonesia belum mempunyai pendidikan karakter yang efektif untuk menjadikan bangsa Indonesia yang berkarakter (tercermin dari tingkah lakunya). Padahal ada beberapa mata pelajaran yangberisikan tentang pesan-pesan moral, misalnya pelajaran agama, kewarganegaraan, dan pancasila. Namun proses pembelajaran yang dilakukan adalah dengan pendekatan penghafalan (kognitif). Para siswa diharapkan dapat menguasai materi yang keberhasilannya diukur hanya dengan kemampuan anak menjawab soal ujian (terutama dengan pilihan berganda). Karena orientasinya hanyalah semata-mata hanya untuk memperoleh nilai bagus, maka bagaimana mata pelajaran dapat berdampak kepada perubahan perilaku, tidak pernah diperhatikan. Sehingga apa yang terjadi adalah kesenjangan antara pengetahuan moral (cognition) dan perilaku (action). Semua orang pasti mengetahui bahwa berbohong dan korupsi itu salah dan melanggar ketentuan agama, tetapi banyak sekali orang yang tetap melakukannya. Tujuan akhir dari pendidikan karakter adalah bagaimana manusia dapat berperilaku sesuai dengan kaidah-kaidah moral.

Tidak bisa dipungkiri bahwa bangsa Indonesia tidak pernah berhenti dalam menyelenggaanrakan program pendidikan dalam keadaan bagaimanapun juga. Namun hingga saat ini keadaan bangsa kita masih mengalami kondisi yang yang tidak kondusif. Bahkan berkembangnya prilaku baru yang sebelum era global tidak banyak muncul, kini cenderung meluas, antara lain: (1) meningkatnya kekerasan di kalangan masyarakat; (2) penggunaan bahasa dan kata-kata yang memburuk, cenderung tidak menggunakan kata baku; (3) pengaruh peer-group (geng) yang kuat dalam tindak kekerasan; (4) meningkatnya perilaku merusak diri, seperti penggunaan narkoba, alkohol, dan seks bebas; (5) semakin kaburnya 
pedoman moral baik dan buruk; (6) menurunnya etos kerja; (7) semakin rendahnya rasa hormat kepada orang tua dan guru; (8) rendahnya rasa tanggung jawab individu dan warga negara; (9) membudaya-nya ketidakjujuran; dan (10) adanya rasa saling curiga dan kebencian di antara sesama

Pendidikan karakter pada anak usia sekolah dasar, dewasa ini sangat diperlukan dikarenakan saat ini Bangsa Indonesia sedang mengalami krisis karakter dalam diri anak bangsa. Karakter di sini adalah watak, tabiat, akhlak, atau kepribadian seseorang yang terbentuk dari hasil internalisasi berbagai kebajikan yang diyakini dan digunakan sebagai landasan untuk cara pandang, bepikir, bersikap, dan bertindak. Kebajikan tersebut berupa Sejumlah nilai moral, dan norma, seperti jujur, berani bertindak, dapat dipercaya, hormat pada orang lain, disiplin, mandiri, kerja keras, kreatif. Berbagai permasalahan yang melanda bangsa belakangan ini ditengarai karena jauhnya kita dari karakter, oleh karena itu pentingnya menciptakan sekolah yang berkarakter.

Sekolah adalah tempat yang strategis untuk pendidikan karakter karena anakanak dari semua lapisan akan mengenyam pendidikan di sekolah. Selain itu anakanak menghabiskan sebagian besar waktunya di sekolah, sehingga apa yang didapatkannya di sekolah akan mempengaruhi pembentukan karakternya.

\section{B. Rumusan Masalah}

Berdasarkan latar belakang di atas, maka dapat dirumuskan masalah sebagai berikut:

1. Apa yang dimaksud dengan Hakikat Sekolah Berkarakter?

2. Bagaimana cara membuat sekolah menjadi sekolah yang berkarakter?

3. Bagaimana cara melibatkan para siswa dalam menciptakan sekolah berkarakter?

\section{Tujuan Makalah}

Makalah ini bertujuan untuk menjelaskan:

1. Untuk mengetahui makna dari Hakikat Sekolah Berkarakter?

2. Bagaimana cara membuat sekolah menjadi sekolah yang berkarakter? 
3. Bagaimana cara melibatkan para siswa dalam menciptakan sekolah berkarakter?

\section{BAB II \\ PEMBAHASAN}

\section{A. Hakikat Sekolah Berkarakter}

Sebelum lebh jauh membahas mengenai hakikat dari sekolah berkarakter maka terlebih dahulu kita mengetahui arti dari karakter itu sendiri. Menurut Simon Philips dalam Buku Refleksi Karakter Bangsa (2008:235), karakter adalah kumpulan tata nilai yang menuju pada suatu sistem, yang melandasi pemikiran, sikap, dan perilaku yang ditampilkan. Sedangkan Doni Koesoema A (2007:80) memahami bahwa karakter sama dengan kepribadian. Kepribadian dianggap sebagai "ciri, atau karakteristik, atau gaya, atau sifat khas dari diri seseorang yang bersumber dari bentukanbentukan yang diterima dari lingkungan, misalnya lingkungan keluarga pada masa kecil dan juga bawaan seseorang sejak lahir." Hal yang selaras disampaikan dalam Buku Refleksi Karakter Bangsa (2008:233) yang mengartikan karakter bangsa sebagai kondisi watak yang merupakan identitas bangsa.

Sementara Winnie memahami bahwa istilah karakter diambil dari bahasa Yunani yang berarti 'to mark' (menandai). Istilah ini lebih fokus pada tindakan atau tingkah laku. Ada dua pengertian tentang karakter. Pertama, ia menunjukkan bagaimana seseorang bertingkah laku. Apabila seseorang berperilaku tidak jujur, kejam, atau rakus, tentulah orang tersebut memanifestasikan perilaku buruk. Sebaliknya, apabila seseorang berperilaku jujur, suka menolong, tentulah orang tersebut memanifestasikan karakter mulia. Kedua, istilah karakter erat kaitannya dengan 'personality'. Seseorang baru bisa disebut 'orang yang berkarakter' (a person of character) apabila tingkah lakunya sesuai kaidah moral. Sedangkan Imam Ghozali menganggap bahwa karakter lebih dekat dengan akhlaq, yaitu spontanitas manusia dalam 
bersikap, atau melakukan perbuatan yang telah menyatu dalam diri manusia sehingga ketika muncul tidak perlu dipikirkan lagi.

Dari pendapat di atas difahami bahwa karakter itu berkaitan dengan kekuatan moral, berkonotasi 'positif', bukan netral. Jadi, 'orang berkarakter' adalah orang yang mempunyai kualitas moral (tertentu) positif. Dengan demikian, pendidikan membangun karakter, secara implisit mengandung arti membangun sifat atau pola perilaku yang didasari atau berkaitan dengan dimensi moral yang positif atau baik, bukan yang negatif atau buruk. Hal ini didukung oleh Peterson dan Seligman (Gedhe Raka, 2007:5) yang mengaitkan secara langsung 'character strength' dengan kebajikan. Character strength dipandang sebagai unsur-unsur psikologis yang membangun kebajikan (virtues). Salah satu kriteria utama dari 'character strength' adalah bahwa karakter tersebut berkontribusi besar dalam mewujudkan sepenuhnya potensi dan cita-cita seseorang dalam membangun kehidupan yang baik, yang bermanfaat bagi dirinya, orang lain, dan bangsanya

Sedangkan Pendidikan karakter merupakan pemahaman akan nilainilai agama, budaya, dan sosial yang mampu membentuk akhlak manusia menjadi lebih bermoral dan berbudi pekerti luhur sehingga mampu menilai dan meneladani sikap yang baik dalam kehidupan mereka sehari-hari.

Sekolah merupakan sebuah tempat dimana proses pendidikan terjadi secara formal. Sekolah merupakan ujung tombak terlaksananya proses pendidikan. Di sekolah terjadi proses transfer ilmu, yang dinamakan proses belajar. Sehingga sekolah merupakan tempat penanaman nilai-nilai ataupun ilmu pada peserta didik, yang akan membentuk pribadi-pribadi unggul yang cerdas dan berkarakter.

Sekolah berkarakter adalah upaya sekolah untuk menanamkan nilainilai budaya karakter dalam diri setiap warga sekolah melalui berbagai kegiatan baik dalam proses pembelajaran intrakurikuler, ekstrakurikuler, maupun penciptaan suasana lingkungan sekolah sehingga budaya karakter menjadi sikap batin (believe system) serta menjadi landasan dalam bersikap dan bertingkah laku. Oleh karena itu proses pembelajaran menjadi sangat penting 
di dalamnya, sebagai sarana menanamkan nilai-nilai karakter yang berbudaya.

\section{Nilai-Nilai Yang Dikembangkan}

Bangsa indonesia adalah bangsa yang berbudaya. berbagai nilainilai budaya yang tumbuh di masyarakat sangat di junjung tinggi. Namun seiring berkembangnya arus globalisasi, nilai-nilai tersebut semakin pudar. Budaya-budaya yang saling berakulturasi, dirasa menarik sehingga mulai ditiru sebagai budaya anak muda. Oleh karena itu dirasa perlu dan penting untuk menanamkan nilai-nilai luhur bangsa pada proses pendidikan di sekolah. Sehingga membentuk siswa yang berkarakter budaya. ${ }^{1}$

Nilai-nilai budaya yang tumbuh dari bangsa Indonesia adalah hasil pewarisan (inheritance) dari nenek moyang. Nilai-nilai tersebut diambil dari nilai-nilai kehidupan jati diri bangsa Indonesia. Nilai-nilai tersebut juga muncul dari berbagai sumber, sumber yang menjadi pandangan hidup bangsa indonesia. Berikut adalah sumber-sumber dari nilai budaya bangsa:

- Agama: masyarakat Indonesia adalah masyarakat beragama. Oleh karena itu, kehidupan individu, masyarakat, dan bangsa selalu didasari pada ajaran agama dan kepercayaannya. Secara politis, kehidupan kenegaraan pun didasari pada nilai-nilai yang berasal dari agama. Atas

\footnotetext{
1 Saihu, S. (2019). RINTISAN PERADABAN PROFETIK UMAT MANUSIA MELALUI PERISTIWA TURUNNYA ADAM AS KE-DUNIA. Mumtaz: Jurnal Studi Al-Quran dan Keislaman, 3(2), 268-279,

Saihu, S. (2019). Pendidikan Pluralisme Agama: Kajian tentang Integrasi Budaya dan Agama dalam Menyelesaikan Konflik Sosial Kontemporer. Jurnal Indo-Islamika, 9(1), 67-90,

Saihu, S. (2019). IMPLEMENTASI MANAJEMEN BALANCED SCORECARD DI PONDOK PESANTREN JAM'IYYAH ISLAMIYYAH TANGERANG SELATAN. Mumtaz: Jurnal Studi Al-Quran dan Keislaman, 3(1), 1-22.

Saihu, S. (2019). KOMUNIKASI PENDIDIK TERHADAP ANAK BERKEBUTUHAN KHUSUS DI SEKOLAH KHUSUS ASY-SYIFA LARANGAN. Andragogi: Jurnal Pendidikan Islam dan Manajemen Pendidikan Islam, 1(3), 418-440.

Saihu, S., \& Marsiti, M. (2019). PENDIDIKAN KARAKTER DALAM UPAYA MENANGKAL RADIKALISME DI SMA NEGERI 3 KOTA DEPOK, JAWA BARAT. Andragogi: Jurnal Pendidikan Islam dan Manajemen Pendidikan Islam, 1(1), 23-54.

Saihu, S. (2019). KONSEP MANUSIA DAN IMPLEMENTASINYA DALAM PERUMUSAN TUJUAN PENDIDIKAN ISLAM MENURUT MURTADHA MUTHAHHARI. Andragogi: Jurnal Pendidikan Islam dan Manajemen Pendidikan Islam, 1(2), 197-217.
} 
dasar pertimbangan itu, maka nilai-nilai pendidikan budaya dan karakter bangsa harus didasarkan pada nilai-nilai dan kaidah yang berasal dari agama.

- Pancasila: negara kesatuan Republik Indonesia ditegakkan atas prinsip-prinsip kehidupan kebangsaan dan kenegaraan yang disebut Pancasila. Pancasila terdapat pada Pembukaan UUD 1945 dan dijabarkan lebih lanjut dalam pasal-pasal yang terdapat dalam UUD 1945.Artinya, nilai-nilai yang terkandung dalam Pancasila menjadi nilai-nilai yang mengatur kehidupan politik, hukum, ekonomi, kemasyarakatan, budaya, dan seni. Pendidikan budaya dan karakter bangsa bertujuan mempersiapkan peserta didik menjadi warga negara yang lebih baik, yaitu warga negara yang memiliki kemampuan, kemauan, dan menerapkan nilai-nilai Pancasila dalam kehidupannya sebagai warga negara.

- Budaya: sebagai suatu kebenaran bahwa tidak ada manusia yang hidup bermasyarakat yang tidak didasari oleh nilai-nilai budaya yang diakui masyarakat itu. Nilai-nilai budaya itu dijadikan dasar dalam pemberian makna terhadap suatu konsep dan arti dalam komunikasi antaranggota masyarakat itu. Posisi budaya yang demikian penting dalam kehidupan masyarakat mengharuskan budaya menjadi sumber nilai dalam pendidikan budaya dan karakter bangsa.

- Tujuan Pendidikan Nasional: sebagai rumusan kualitas yang harus dimiliki setiap warga negara Indonesia, dikembangkan oleh berbagai satuan pendidikan di berbagai jenjang dan jalur. Tujuan pendidikan nasional memuat berbagai nilai kemanusiaan yang harus dimiliki warga negara Indonesia. Oleh karena itu, tujuan pendidikan nasional adalah sumber yang paling operasional dalam pengembangan pendidikan budaya dan karakter bangsa. ${ }^{2}$

2 Saihu, S., \& Rohman, B. (2019). PEMBENTUKAN KARAKTER MELALUI MODEL PENDIDIKAN TRANSFROMATIFE LEARNING PADA SANTRI DI PONDOK PESANTREN NURUL IKHLAS BALI. Edukasi Islami: Jurnal Pendidikan Islam, 8(02), 435-452. 
Sumber-sumber ini merupakan pandangan atau falsafah hidup bangsa Indonesia. Dimana didalamnya terdapat nilai-nilai luhur jati diri bangsa Indonesia. Kemudian bersumber dari nilai-nilai tersebut, Departemen Pendidikan Nasional pada tahun 2011 menetapkan 18 nilai yang wajib disisipkan pada setiap aktivitas sekolah. hal ini di umumkan oleh Presiden Susilo Bambang Yudhoyono. Berikut 18 nilai pembentuk karakter:

1. Religius: Sikap dan perilaku yang patuh dalam melaksanakan ajaran agama yang dianutnya, toleran terhadap pelaksanaan ibadah agama lain, dan hidup rukun dengan pemeluk agama lain.

2. Jujur : Perilaku yang didasarkan pada upaya menjadikan dirinya sebagai orang yang selalu dapat dipercaya dalam perkataan, tindakan, dan pekerjaan.

3. Toleransi : Sikap dan tindakan yang menghargai perbedaan agama, suku, etnis, pendapat, sikap, dan tindakan orang lain yang berbeda dari dirinya.

4. Disiplin: Tindakan yang menunjukkan perilaku tertib dan patuh pada berbagai ketentuan dan peraturan.

5. Kerja Keras :Tindakan yang menunjukkan perilaku tertib dan patuh pada berbagai ketentuan dan peraturan.

6. Kreatif : Berpikir dan melakukan sesuatu untuk menghasilkan cara atau hasil baru dari sesuatu yang telah dimiliki.

7. Mandiri : Sikap dan perilaku yang tidak mudah tergantung pada orang lain dalam menyelesaikan tugas-tugas.

Saihu, S., \& Taufik, T. (2019). PERLINDUNGAN HUKUM BAGI GURU. Al Amin: Jurnal Kajian Ilmu dan Budaya Islam, 2(2), 105-116.

Saihu, S. (2020). KONSEP PEMBAHARUAN PENDIDIKAN ISLAM MENURUT FAZLURRAHMAN. Andragogi: Jurnal Pendidikan Islam dan Manajemen Pendidikan Islam, 2(1), 82-95.

Saihu, S. (2020). ETIKA MENUNTUT ILMU MENURUT KITAB TA'LIM MUTA'ALIM. $A l$ Amin: Jurnal Kajian Ilmu dan Budaya Islam, 3(1), 99-112.

Saihu, Aziz, A., Mubin, F., \& Sarnoto, A. Z. (2020). Design of islamic education based on local wisdom (An analysis of social learning theories in forming character through ngejot tradition in bali). International Journal of Advanced Science and Technology, 29(6), 1278-1293. 
8. Demokratis : Cara berfikir, bersikap, dan bertindak yang menilai sama hak dan kewajiban dirinya dan orang lain.

9. Rasa Ingin Tahu : Sikap dan tindakan yang selalu berupaya untuk mengetahui lebih mendalam dan meluas dari sesuatu yang dipelajarinya, dilihat, dan didengar.

10. Semangat Kebangsaan : Cara berpikir, bertindak, dan berwawasan yang menempatkan kepentingan bangsa dan negara di atas kepentingan diri dan kelompoknya.

11. Cinta Tanah Air : Cara berpikir, bertindak, dan berwawasan yang menempatkan kepentingan bangsa dan negara di atas kepentingan diri dan kelompoknya.

12. Menghargai Prestasi : Sikap dan tindakan yang mendorong dirinya untuk menghasilkan sesuatu yang berguna bagi masyarakat, dan mengakui, serta menghormati keberhasilan orang lain.

13. Bersahabat/Komunikatif : Sikap dan tindakan yang mendorong dirinya untuk menghasilkan sesuatu yang berguna bagi masyarakat, dan mengakui, serta menghormati keberhasilan orang lain.

14. Cinta Damai : Sikap dan tindakan yang mendorong dirinya untuk menghasilkan sesuatu yang berguna bagi masyarakat, dan mengakui, serta menghormati keberhasilan orang lain.

15. Gemar Membaca : Kebiasaan menyediakan waktu untuk membaca berbagai bacaan yang memberikan kebajikan bagi dirinya.

16. Peduli Lingkungan : Sikap dan tindakan yang selalu berupaya mencegah kerusakan pada lingkungan alam di sekitarnya, dan mengembangkan upaya-upaya untuk memperbaiki kerusakan alam yang sudah terjadi.

17. Peduli Sosial : Sikap dan tindakan yang selalu ingin memberi bantuan pada orang lain dan masyarakat yang membutuhkan.

18. Tanggung Jawab: Sikap dan perilaku seseorang untuk melaksanakan tugas dan kewajibannya, yang seharusnya dia lakukan, 
terhadap diri sendiri, masyarakat, lingkungan (alam, sosial dan budaya), negara dan Tuhan Yang Maha Esa. ${ }^{3}$

\section{Membangun Pribadi Berkarakter di Sekolah}

Karena karakter adalah kualitas atau kekuatan mental atau moral, akhlak atau budi pekerti individu yang merupakan kepribadian khusus yang menjadi pendorong atau penggerak, serta yang membedakan dengan individu lain. Seseorang dapat dikatakan berkarakter ketika orang tersebut telah berhasil menyerap nilai dan keyakinan yang dikehendaki masyarakat serta digunakan sebagai kekuatan moral dalam hidupnya (M. Furqon Hidayatullah; 2010). Selain itu membangun karakter juga bertujuan untuk meningkatkan mutu penyelenggaraan dan hasil pendidikan di sekolah yang diharapkan kelak anak didik kita akan mampu secara mandiri meningkatkan dan menggunakan pengetahuannya dalam tindakan mereka sehari-hari.

Membentuk karakter siswa memang tidak semata-mata menjadi tugas guru atau sekolah, melainkan juga keluarga dan masyarakat. Dan guru memiliki peran yang sangat penting dalam pembentukan karakter anak pada pendidikan formal di sekolah. Membangun karakter ini tak terjadi dalam sekejap melalui nasihat, perintah, atau instruksi. Pembentukan karakter memerlukan teladan atau role model, kesabaran, kebiasaan serta budaya sekolah yang kondusif. ${ }^{4}$

\footnotetext{
${ }^{3}$ Ronaldo, R., Zulfikar, A., Saihu, Ismail, \& Wekke, I. S. (2020). International relations of the asia pacific in the age of trump. Journal of Environmental Treatment Techniques, 8(1), 244-246.

Saihu, M. M., \& Aziz, A. (2020). Implementasi Metode Pendidikan Pluralisme Dalam Mata Pelajaran Pendidikan Agama Islam. Belajea; Jurnal Pendidikan Islam, 5(1), 131-150.

Saihu, M. (2019). Urgensi 'Urf dalam Tradisi Male dan Relevansinya dalam Dakwah Islam di Jembrana-Bali. Jurnal Bimas Islam, 12(1), 173-201.

Saihu, S. (2020). The Effect of Using Talking Stick Learning Model on Student Learning Outcomes in Islamic Primary School of Jamiatul Khair, Ciledug Tangerang. Tarbawi: Jurnal Keilmuan Manajemen Pendidikan, 6(01), 61-68.

Saihu, S. (2020). Pendidikan sosial yang terkandung dalam Surat At-Taubah Ayat 71-72. Edukasi Islami: Jurnal Pendidikan Islam, 9(01), 127-148.

4 Aziz, A., \& Saihu, S. (2019). Interpretasi Humanistik Kebahasaan: Upaya Kontekstualisasi Kaidah Bahasa Arab. Arabiyatuna: Jurnal Bahasa Arab, 3(2), 299-214
} 
Untuk itu penting sekali seorang guru menguasai karakteristik peserta didiknya, karena berdasarkan peraturan menteri Pendidikan Nasional RI Nomor 35 Tahun 2010 tentang Petunujuk teknis pelaksana jabatan fungsional guru dan angka kreditnya (Kemendiknas, 2011:26) bahwa salah satu kompetensi pedagogik yang harus dikuasai dan dilaksanakan oleh guru sebagai bagian dari upaya mewujudkan kinerja yang efektif dan optimal adalah menguasai karakteristik peserta didik.

Beberapa manfaat yang dapat diperoleh guru dari hasil kajian terhadap karakteristik peserta didik yang dihadapi guru dikelas Antara lain.

1. Guru memperoleh gambaran yang lengkap dan terperinci tentang kemampuan awal para peserta didik, yang berfungsi sebagai prere kuisit bagi bahan barun yang akan disampaikan.

2. Memperoleh gambaran tentang luas dan jenis pengalaman yang telah dimiliki oleh peserta didik

3. Mengetahui latar belakang social kultur para peserta didik , termasuk latar belakang keluarganya yang melatar belakangi perkembangan social emosionla dan mental mereka.

4. Mengetahui tingkat pertumbuhan dan perkembangan peserta didik baik jasmani maupun rohaniah.

5. Mengetahui aspirasi dna kebutuhan para peserta didik

Saihu, S. (2019). PENDIDIKAN KARAKTER BERBASIS KEARIFAN LOKAL (STUDI DI JEMBRANA BALI). Edukasi Islami: Jurnal Pendidikan Islam, 8(01), 69-90.

Şahin, C. RELIGIA.

Saihu, S., \& Mailana, A. (2019). Teori pendidikan behavioristik pembentukan karakter masyarakat muslim dalam tradisi Ngejot di Bali. Ta'dibuna: Jurnal Pendidikan Islam, 8(2), 163176.

Mubin, F. KEADILAN DALAM GENDER: KAJIAN KEPEMIMPINAN WANITA DALAM ISLAM1,

Saihu, M. (2019). Merawat Pluralisme Merawat Indonesia (Potret Pendidikan Pluralisme Agama Di Jembrana-Bali). Deepublish.

Mubin, F. (2019). TAFSIR EMANSIPATORIS: PEMBUMIAN METODOLOGI TAFSIR

PEMBEBASAN. Mumtaz: Jurnal Studi Al-Quran dan Keislaman, 3(1), 131-151.

Mubin, F. MODEL-MODEL PEMBELAJARAN BERBASIS MADRASAH DAN KEGIATAN

LAIN YANG DIPERLUKAN DI DALAMNYA (FAKTOR PENDUKUNGNYA). 
6. Mengetahui tingkat penguasaan pengetahuan yang telah diperoleh oleh peserta didik sebelumnya.

7. Mengetahui tingkat penguasaan Bahasa peserta didik, baik lisan maupun tertulis.

8. Dapat mengetahui sikap dan nilai yang menjiwai peserta didik.

Pribadi yang berkarakter adalah perwujudan dari totalitas psikologis yang mencakup seluruh potensi individu (kognitif, afektif, dan psikomotorik) dan fungsi totalitas sosial-kultural dalam konteks interaksi (dalam keluarga, satuan pendidikan, dan masyarakat) dan berlangsung sepanjang hayat. Konfigurasi karakter dalam kontek totalitas proses psikologis dan sosial-kultural dapat dikelompokkan dalam: (1) olah hati (spiritual \& emotional development); (2) olah pikir (intellectual development); (3) olah raga dan kinestetik (physical \& kinesthetic development); dan (4) olah rasa dan karsa (affective and creativity development).

Untuk membentuk pribadi yang berkarakter perlu adanya korelasi yang baik antara warga sekolah. baik dari kepala sekolah, guru maupun karyawan harus sadar akan karakter yang mereka bawakan. Sekolah harus bisa membentuk lingkungan yang kondusif bagi siswa sesuai dengan nilainilai karakter yang baik. Berikut adalah cara-cara sekolah dalam membentuk karkater siswa :

a. Kegiatan Pembelajaran

Kegiatan pembelajaran dalam kerangka pengembangan karakter peserta didik dapat menggunakan pendekatan kontekstual sebagai konsep belajar dan mengajar yang membantu guru dan peserta didik mengaitkan antara materi yang diajarkan dengan situasi dunia nyata, sehingga peserta didik mampu untuk membuat hubungan antara pengetahuan yang dimilikinya dengan penerapannya dalam kehidupan mereka. Dengan begitu, melalui pembelajaran kontekstual peserta didik lebih memiliki hasil yang komprehensif tidak hanya pada tataran kognitif (olah pikir), tetapi pada tataran afektif (olah hati, rasa, dan 
karsa), serta psikomotor (olah raga).Pembelajaran kontekstual mencakup beberapa strategi, yaitu: (a) pembelajaran berbasis masalah, (b) pembelajaran kooperatif, (c) pembelajaran berbasis proyek, (d) pembelajaran pelayanan, dan (e) pembelajaran berbasis kerja. Kelima strategi tersebut dapat memberikan nurturant effect pengembangan karakter peserta didik, seperti: karakter cerdas, berpikir terbuka, tanggung jawab, rasa ingin tahu.

2. Pengembangan Budaya Sekolah dan Pusat Kegiatan Belajar Pengembangan budaya sekolah dan pusat kegiatan belajar dilakukan melalui kegiatan pengembangan diri, yaitu:

\section{a. Kegiatan rutin}

Kegiatan rutin yaitu kegiatan yang dilakukan peserta didik secara terus menerus dan konsisten setiap saat. Misalnya kegiatan upacara hari Senin, piket kelas, shalat berjamaah, berdo'a sebelum pelajaran dimulai dan diakhiri, dan mengucapkan salam apabila bertemu guru, tenaga pendidik, dan teman.

\section{b. Kegiatan spontan}

Kegiatan yang dilakukan peserta didik secara spontan pada saat itu juga, misalnya, mengumpulkan sumbangan ketika ada teman yang terkena musibah atau sumbangan untuk masyarakat ketika terjadi bencana.

\section{c. Keteladanan}

Merupakan perilaku dan sikap guru dan tenaga kependidikan dan peserta didik dalam memberikan contoh melalui tindakan-tindakan yang baik sehingga diharapkan menjadi panutan bagi peserta didik lain. Misalnya nilai disiplin, kebersihan dan kerapihan, kasih sayang, kesopanan, perhatian, jujur, dan kerjakeras.

d. Pengkondisian

Pengkondisian yaitu penciptaan kondisi yang mendukung keterlaksanaan pendidikan karakter, misalnya kondisi toilet yang 
bersih, tempat sampah, halaman yang hijau dengan pepohonan, poster kata-kata bijak yang dipajang di lorong sekolah dan di dalam kelas.

e. Kegiatan ko-kurikuler dan atau kegiatan ekstrakurikuler

Demi terlaksananya kegiatan ko-kurikuler dan ekstrakurikuler yang mendukung pendidikan karakter, perlu didukung dengan dengan perangkat pedoman pelaksanaan, pengembangan kapasitas sumber daya manusia dalam rangka mendukung pelaksanaan pendidikan karakter, dan revitalisasi kegiatan ko dan ekstrakurikuler yang sudah ada ke arah pengembangan karakter.

f. Kegiatan keseharian di rumah dan di masyarakat

Dalam kegiatan ini sekolah dapat mengupayakan terciptanya keselarasan antara karakter yang dikembangkan di sekolah dengan pembiasaan di rumah dan masyarakat. Agar pendidikan karakter dapat dilaksanakan secara optimal, pendidikan karakter dapat diimplementasikan sebagaimana yang telah di ajarkan di sekolah.

\section{B. Cara Membuat Sekolah Menjadi Sekolah Yang Berkarakter}

Strategi untuk menjadi sekolah yang berkarakter harus ada keterlibtatan staf, keterlibtan siswa, dan keterlibatan orang tua. Semua itu merupakan tiga kelompok yang partisipasinya bersifat krusial bagi keberhasilan inisiatif pendidikan karakter sebuah sekolah.

\section{Menciptakan Tonggak}

Dalam panduan implementasinya, Educating for Character in the Denver Public School, Charles Elbot, dan beberapa evens menulis demikian, "banaya sekolah yang telah menciptakan pendidikan karakter yang mendalam dan dipertahankan telah melaksanakan program tersebut dengan bantuan tonggak di seluruh sekolah". Tonggak ini merupakan pernyataan atau cara yang mengekspresikan nilai dan aspirasi bersama dari seluruh anggota komunis sekolah tersebut.

Menciptakan tonggak sekolah dapat diawali dengan meneliti pernyataan misi sekolah tersebut (biasanya lebih lama, lebih kompleks, dan sulit untuk 
diingat dari pada tunggak apa pun). Nilai etika dan intelektual apakah yang diekspresikan oleh misi tersebut? Nilai apakah yang hilang atau harus dibuat lebih eksplisit dalam sebuah tonggak? Suatu komite sekolah kemudian dapat menuliskan empat atau lima pernyataan "kami",seperti yang ada dalam cara Slaven untuk dikemukakan sebagai pernyataan atau tonggak sekolah dan mendengarkan rancangan ini sepada seluruh staf, siswa dan orang untuk mendapatkan masukan dari mereka.

\section{Memiliki Motto Berbasis Karakter}

Apakah pernyaaan sekolah, hidup dalam hati dan pikiran para staf dan siswa? Salah satu cara untuk membantu hal tersebut menjadi kenyataan adalah memilih motto sekolah, salah satu pernyataan keyakinan dalam tonngak yang dimiliki terhadap tonggak tersebut dan membuat motto tersebut menjadi bagian penting dalam kebudayaan sekolah. Berikut adalah contoh motto sekolah:

\section{Memperkenelkan Konsep Pendidikan Karakter Kepada Seluruh}

\section{Staf}

Mengundang seluruh personel sekolah untuk menghadiri pertemuan pengantarmengenai pendidikan karakter. Sesi pengantar ini harus mengemukakan 4 hal pernyataan yang mendasar: (1) apakah sasaran dari pendidikan karakter? (2) apakah yang akan diperlikan dalam diri saya, dalam pekerjaan saya? (3) apakah yang akan terjadi apabila kita melaksanakan di seluruh sekolah? (4) apakah keuntungan yang akan diperoleh jika kita melaksanakan program ini?.

\section{Mempertimbangkan " Tipe Kepribadian Macam Apakah yang Kita Inginkan dari para Siswa?"}

Sasaran pendidikan karakter ada tiga: kepribadian berkarakter, baik, sekolah berkarakter, dan masyarakat berkarakter. Maka muncul pertanyaan “apakah yang dimaksud dengan karakter yang baik?”. Para staf hendaknya menyadari kualitas yang dimiliki dirinya dan kualitas yang akan 
dihasilkannya. Karakter yang baik memiliki 10 kebijakan esensial yang dideskripsikan sebelumnya beserta dengan kebijakan yang akan mendukungnya.

1. Kebijaksanaan

2. Keadilan

3. Ketabahan

4. Mengendalikan diri

5. Saling mengasihi

6. Sikap positif

7. Kerja keras

8. Integritas

9. Terima kasih

10. Kerendahan hati

\section{Menganalisis Kebudayaan Moral dan Intelektual Sekolah}

Langkah berikutnya adalah melihat dengan lebih dekat kekuatan dan area bagi peningkatan dalam kebudayaan moral dan intelektual sekolah. Langkah ini merupakan langkah yang sangat dibutuhkan dalam menciptakan sekolah yang berkarakter. Apabila langkah ini tidak diambil maka suatu sekolah dapat mengabaikan "gajah yang ada di meja" yaitu permasalahan yang ada tepat dibawah hidung kita, yang tidak dikemukakan akan mengikis usaha pendidikan karakter.

Suatu cara sistematis untuk merefleksikan pengalaman ini adalah menggunakan analisis empat bagian berikut ini terhadap kebudayaan maral dan intelektual sekolah. Analisis ini dapat dilengkapi secara individual oleh staf sebelum pertemuan staf diadakan, dengan hasil yang dikumpulkan dan dipresentasikan oleh kelompok kepemiminan pendidikan karakter, atau dapat dilengkapi dan dibahas dalam kelompok yang terdiri dari tiga atau empat orang dalam pertemuan staf.

\section{Merencanakan Program Pendidkan Karakter Berkualitas}


Tantangan dalam tahap ini adalah mendesain suatu program yang memiliki segian besar komponen yang membentuk pendidikan karakter yang berkualitas. Berikut ini merupakan komponen pendidikan karakter yang berulang kali muncul dalam kisah kesuksesan pendidikan karakter.

a. Kepemimpinan/ dukungan administrative

b. Keterlibatan staf yang kuat

c. Keterlibatan siswa yang kuat

d. Keterlibatan orang tua yang kuat

e. Tonggak sekolah dan motto yang menekankan karakter

f. Pemakaian bahasa karakter dalam interaksi setiap hari dan kode prilaku

g. Perangkat kebaikan sasaran yang disetujui

h. Perencanaan di seluruh sekolah untuk secara sengaja mendorong dan mengajar sasaran kebaikan sekolah

i. Contoh prilaku yang dihasilkan oleh staf tentang hal bagaimana "tampak" dan "bunyi" kabaikan ini pada berbagai usia dan bagian lingkungan sekolah yang berbeda.

j. Penekanan pada tanggung jawab seluruh sekolah dan siswa untuk memodelkan kebaikan.

k. Integrasi kebaikan ini secara berkesinambungan ke dalam intruksi di seluruh kurikulum

1. Pemakaian pendidikan kurikulum pendidikan karakter yang dipublikasukan, dimanapun pemakaian tepat dilakukan.

m. Suatu pendekatan terhadap disiplin yang mengajarkan kebaikan dan meenghargai karakteryang baik dengan cara menjaga focus pada alasan karakter karena melakukan apa yang benar.

n. Usaha diseluruh sekolah untuk mengembangkan komunitas yang peduli guna mencegah kenakalan di antara teman sebaya.

o. Lingkungan yang kaya karakter visual

p. Memperkerjakan staf yang memiliki karakter baik dan berkomitmen untuk memodelkan dan mengajarkan karakter. 
q. Pengembangan staf dan keahlian dan strategi pendidikan karakterdan akuntabilitas untuk menggunakannya.

r. Waktu yang dijadwalkan untuk perencanaan, pembagian, dan refleksipara staf atas program karakter yang bersangkutanserta kebudayaan moral dan intelektual sekolah.

s. Adanya dukungan finansial dengan rendah hati.

t. Perencanaan untuk penilaian dampak program yang berkesinambungan.

\section{Memilih Strategi Organisasi untuk Mendorong Kebaikan}

Staf sekolah juaga harus membahas dan memutuskan bagaimana caranya untuk mengorganisir program pendidikan karakternya. Berikut ini merupakan terdapat sepuluh strategi organisasi, yang di antaranya dapat dikombinasikan:
a. Satu kebaikan satu bulan
b. Satu kebaikan satu minggu
c. Tiga atau empat tahun siklus kebaikan
d. Tema tahunan
e. Penugasan kebaikan yang tepat menurut perkembangannya kepada masing-masing tingkat kelas.
f. Perangkat ekspektasi perangkat karakter yang lazim
g. Kerangka kerja kurikulum pendidikan karakter
h. Kurikulum pendidikan karakter yang dipublikasikan
i. Suatu "model proses" pendidikan karakter
j. Pendekatan kebudayaan sekolah

\section{Membuat Penilaian sebagai Bagian dari Perencanaan}

Ada tiga alasan penting untuk mengadakan penilain terhadap pendidikan karakter, yaitu: (1) apa yang diukur, misalnya motivasi dan akuntabilitas staf untuk mengimplementasikan usaha pendidikan k9arakter 
akan menjadi jauh lebih besar apabila terdapat perencanaan untuk menilai hasil; (2) penilain akan memberikan informasi kepada kita samapai tingkat manakah program pendidkan karakter kita sebenarnya membuat perbedaan; (3) data penilai dapat digukan untuk memandu pengambilan keputusan tentang bagaimana caranya meningkatkan keefektifan program tersebur.

Dalam penilaian harus mencoba menjawab keempat pertanyaan berikut ini:

a. Sampai tingkat manakah para staf mengimplementasikan program pendidikan karakter sebagaimana yang diinginkan?

b. Sampai tingkat manakah para siswa memahami kebaikan sasaran yang diajarkan di kelas mereka?

c. Sampai tingkat manakah para siswa berkembang dalam hal mempraktikkan kebaikan tersebut?

d. Sampai tingkat manakah prilaku para siswa mengalami peningkatan atau perbaikan dalam bagian tertentu di lingkungan sekolah atau di dalam kehidupan sekolah.

\section{Meluangkan Waktu bagi Karakter}

Kurangnya waktu merupakan musuh nomor satu bagi reformasi pendidikan berkelanjutan. Suatu sekolah perlu menemukan waktu untuk mengejar sasaran pendidikan karakter dalam kesempurnaan moral dan intelektual. Menurut Pat Floyd-Echols, Kepala Sekolah K-5 Dr. Martin Luther King, Jr. Magnet school ditengah kota syracuse, New York, sekarang kami mencurahkan seluruh pertemuan fakultas kami untuk sharing dan pengembanga staf. Menggunakan pertemuan antar fakultas kami lebih produktif dan membuat hubungan dengan staf semakin dekat. Dalam dua tahun terakhir hal ini juga mampu untuk meningkatkan nilai matematika siswa dengan menjadi lebih konsisten dalam pendekatan intruksional kami.

Aktivitas pengembangan staf lainnya yang bagus adalah proyek buku yang lazim. Para staf berkomitmen untuk membaca dan membahas sebuah buku yang berhubungan dengan pengembangan karakter sebagai bagian dari pertemuan fakultas. Dukungan untuk jenis pengembangan orang dewasa ini 
mutlak penting untuk mencapai sekolah berkarakter. Sebagimana yang dijelaskan oleh Rick Weissbourd, penulis The Vulnerable Child, "kita tidak akan pernah meningkatkan secara pesat pengembangan moral siswa adisekolah tanpa menempuh tugas kelompok untuk mengembangkan kedewasaan dan kapasitas etika oranag dewasa. "kita tidak dapat memberikan apa yang tidak kita miliki.

Sebagian besar perubahan pendidikan berlangsung singkat ; ada disini pada hari ini, besok pagi sudah menghilang. Itulah alasannya mengapa para guru sering kali bersikap sinis, berfikiran demikian, "yang ini juga akan berlalu." Urusan menjadi sekolah yang berkarakter tidak boleh menjadi tren yang lewat, karena mengembangkan karakter yang baik berada pada jantung pendidikan sekolah yang efektif dan itulah yang dimaksud dengan menjadi manusia.

Reformasi pendidikan yang tahan lama, reformasi dengan kekuatan untuk mengubah atau mentransformasikan kebudayaan sekolah, reformasi yang masih berada garis depan kesadaran kolektif sekolah. Dari waktu ke waktu, reformasi ini menjdai bagian dari identitas sekolah, bagaimana reformasi tersebut mendefinisikan dirinya sendiri. Untuk memiliki jenis kekuatan transformasi tersebut, pendidikan karakter yang harus dipikirkan dan dibahas secara teratur oleh sejumlah besar sataf., secara khusus oleh para guru inti yang berkomitmen yang dapat mempertahankan kebudayaan sekolah ketika kepemimpinan administratif berubah. Tantangan untuk hal inti yang penting tersebut adalah menjaga pembicaraan atau pembahasan karakter terus berjalan.

\section{Cara Melibatkan para Siswa dalam Menciptakan Sekolah yang Berkarakter}

Dalam kehidupan moral di sekolah, tidak ada kesempatan yang lebih baik bagi para siswa untuk mengambil kesempatan dalam tanggung jawab otentik selain dari membantu menciptakan sekolah berkarakter. 
Par siswa harus dilibatkan sebagai rekkanan yang penting dalam tugas tersebut. Ketika para siswa berada dalam peranan kepemimpinan yang jelas, dan ketika semua siswa memiliki suara dan patokan dalam usaha pendidikan karakter, orang dewasa akan menjadi jauh lebih efektif dalam mendorong karakter baik dari pada yang dapat mereka lakukan sendiri.

\section{Melibatkan Parasiswa Dalam Merencanakan dan Melaksanakan Program Pendidikan Klarakter}

Diseluruh tingkat usia, para sisiwa dapat memainkan peranan yang bermakna dalam merencanakan dan melaksanakan program pendidikan karakter sekolah.

Diawal setiap bulan, komite karakter anak-anak ( kids character committee) masing-masing kelas memiliki dua kali makan siang waktu bekerja dengan konselor Sigler. Dalam pertemuan tersebut mereka .

1) Membahas bagai mana dan seperti apa cirri karakter bulan ini, serta bagaimana rasanya ketika menunjukan cirri tersebut.

2) Mengembangkan, dengan bantuan sigler, persentasi dan postes yang akan mengajarkan teman satu kelas mereka tentang cirri tersebut.

3) Merencanakan cara-cara tambahan untuk melibatkan kelas mereka dalam mempelajari tentang dan mempraktikan sifat ini selama bulan yang bersangkutan.

\section{Menggunakan Pertemuan Kelas Untuk Memberikan Anak-Anak} Suara Dan Tanggung Jawab .

Pertemuan kelas merupakan suatu diskusi interaktif dimana para siswa berbagi tanggung jawab untuk membuat kelas menjadi tempat yang baik untuk berada dan untuk belajar. Dilakukan dalam lingkaran, yang memampukan setiap anak melihat teman-teman mereka, pertemuan kelas dapat digunakan untuk mengembangkan kode disiplin, merencanakan acara khusus seperti field trip, memecahkan permasalahan kelas, atau memberikan 
konstribusi bagi solusi permasalahan di tingkat sekolah. Dalam beberapa kelas, para siswa dapat meminta pertemuan tentang permasalahan yang ingin mereka kemukakan.

\section{Melibatkann para Siswa dalam Pemerintahan Siswa Partisipatoris Di}

\section{Tingkat Sekolah}

ketika para siswa belajar dan mempraktikan keahlian diskusi dan pengambilan keputusan dalam pertemuan kelas, mereka dipersiapkan untuk berpastisipasi dalam proses yang sangat penting di tingkat sekolah : pemerintahan sisawa yang berbagi tanggung jawab untuk membuat sekolah menjadi tempat yang sebaik mungkin.

Ketika sekolah tidak memiliki jenis pemerintahan siswa semacam ini, maka sekolah sudah pasti akan mengalami ketidak jujuran, vandalism, kenakalan anaksebaya, pelecehan seksual, ketegangan antaras, bahasa buruk, sikap spoortif yang buruk, dan permaslahan lainnya yang semacam itu Karena permasalahan ini terletak dalam kebudayaan anak-anak remaja, maka permasalahan tersebut sulit atau mustahil untuh dipecahkan oleh orang dewasa yang bertindak menurut cara mereka sendiri. Anak-anak diperlukan untuk membantu membentuk norma yang memengaruhi prilaku siswa.

Sekolah memiliki kesempatan yang jauh lebih baik untuk memecahkan permasalahan yang ada dalamlingunganya apabila sekolah merancang pemerintahan siswa partisipaoris. Menurut pendekatan ini, delegasi siswa berpera sebagai perwakilan kelas ( atau homeroom) mereka dan melapor kembali kepada kelas mereka.

\section{Memberikan Kesempatan Informal bagi Masukan Siswa}

Struktur informal dapat melengkapi pekerjaan pemerintahan siswa formal dan memberikan suatu kesempatan untuk berperan dalam meningkatkan sekolah mereka pada siswa tambahan. Misalnya, dua orang konselor di saint Loouise Middle School membentuk apa yang mereka sebut "Klub Makan Pagi ("the Breakfast Club') sebagai satu cara untuk memberikan para siswa kesempata untukmemberikan masukan mengenai sekolah mereka. Kedua orang konselor ini menarik duapuluh ama siswa dari 
dalam topi dan mengundang mereka untuk bertemu dengan mereka selama dua puluh menit sebelum kelas dimulai pada hari kamis.

\section{Menantang Para Siswa untuk Memimpin Kampanye Di Sekolah}

Konselor derba hines ialah penasehat dewan siswa di Carlisle High School di Carsile, Pennsylvania. Dua tahun lalu, beliau mengatakan,pihak administrasi sekolah beiau berada diambang membatalkan acara dansa sekolah karena jumlah siswa yang mimum minuman keras sebelum dan selam acara dansa (dikamar mandi, misalnya ) meningkat. Mminum minuman keras juga berkontribusi bagi sejumlah besar prilaku yeng tidak tepat diatas dan sekitar lantai dansa.

\section{Membentuk System Mentoring}

System mentoring yang didesain dengan baik membantu membentuk norma sekolah yang penting : para siswa yang lebih tua bertanggung jawab untuk menjadi role model yang mendukung bagi para siswa yang lebih muda.

Beberapa sekolah tinggi telah melakukan penelitian tindakan guna mengevaluasi dampak program mentoring senior- siswa baru dan mendapati bahwa para siswa baru yang menerima bimbingan memperoleh nilai yang lebih baik dan kurang memiliki kemungkinan untuk diberi rujukan dengan alas an permasalahan disiplin.

\section{Membentuk Klub Atau Komite Karakter}

Para siswa juga dapat membuat perbedaan dalam karakter sekolah mereka melalui sebuah klub atau komite yang memiliki tanggung jawab di tingkat sekolah.

\section{Menghargai Kepemimpinan Siswa}

Jika kita menginginkan para siswa mengambil peran kepemimpinan dalam meningkatkan sekolah mereka, kita harus member mereka penhargaan ketika mereka melakukannya.

Beberapa distrik, dalam pertemuan penghargaan musim semi tahunannya, memberikan penghargaan secara individual maupun berkelompok kepada para siswa yang telah memberikan kontribusi 
signifikan terhadap peningkatan sekolah mereka. Distrik lainnya mengatur liputan media atas hal-hal baik yan sedang dilakukan para siswa.beberapa konfrensi pndidikan karakter ditingkat regional dan tingkat Negara bagian sekrang mengikutsertakan upacara pengharagaan khusus yang memberikan penghargaan kepada para siswa yang telah membuat perbedaan positif dalam lingkungan sekolah mereka. 
BAB III

KESIMPULAN DAN SARAN

\section{A. Kesimpulan}

a. Sekolah berkarakter adalah upaya sekolah untuk menanamkan nilai-nilai budaya karakter dalam diri setiap warga sekolah melalui berbagai kegiatan baik dalam proses pembelajaran intrakurikuler, ekstrakurikuler, maupun penciptaan suasana lingkungan sekolah sehingga budaya karakter menjadi sikap batin (believe system) serta menjadi landasan dalam bersikap dan bertingkah laku.

Nilai-nilai karakter bersumber pada agama, pancasila, budaya dan tujuan pendidikan nasional. Menurut Diknas ada 18 nilai-nilai pembentuk karakter yaitu Religius, Jujur, Toleransi, Disiplin, Kerja Keras, Kreatif, Mandiri, Demokratis, Semangat Ingin Tahu, Semangat kebangsaan, Cinta Tanah Air, Menghargai Prestasi, Bersahabat/Komunikatif, Cinta Damai, Gemar Membaca, Peduli Lingkungan, Peduli Sosial, Tanggung Jawab.

Pribadi yang berkarakter adalah perwujudan dari totalitas psikologis dalam mencakup seluruh potensi individu (kognitif, afektif, dan psikomotorik) dan fungsi totalitas sosial-kultural dalam konteks interaksi (dalam keluarga, satuan pendidikan, dan masyarakat) dan berlangsung sepanjang hayat. Konfigurasi karakter dalam kontek totalitas proses psikologis dan sosialkultural dapat dikelompokkan dalam: (1) olah hati (spiritual \& emotional development); (2) olah pikir (intellectual development); (3) olah raga dan kinestetik (physical \& kinesthetic development); dan (4) olah rasa dan karsa (affective and creativity development).

b. Strategi untuk menjadi sekolah yang berkarakter harus ada keterlibtatan staf, keterlibtan siswa, dan keterlibatan orang tua. Semua itu merupakan tiga kelompok yang partisipasinya bersifat krusial bagi keberhasilan inisiatif pendidikan karakter sebuah sekolah. Pada makalah ini akan menjelaskan mengenai strategi untuk melibatkan siswa dalam menciptakan sekolah yang berkarakter. 
Cara untuk membuat sekolah kita menjadi sekolah yang berkarakter yaitu: menciptakan tonggak, memilki motto berbasis karakter, menari dukungan kepala sekolah untuk membuat karakter menjadi prioritas, membentuk kelompok kepemimpinan, mengembangkan basis pengetahuan, memperkenalkan konse pendidikan karakter kepada seluruh staf, mempertimbangkan "tipe kepribadian macam apakah yang kita inginkan dari para staf”, mempertimbangkan "apakah arti pendidikan karakter untuk saya?", mempertimbangkan "apakah pendidikan karakter tersebut akan dapat dilaksanaka di seluruh sekolah", memilih dua prioritas untuk meningkatkan kebuadayaan sekolah, bertanyalah "haruskah kita berkomitmen untuk menjadi sekolah berkarakter?", dan merencanakan program pendidikan berkualitas, memilih strategi organisasi untuk mendorong kebaikan, membuat penilaian sebagai bagian dari perencanaan, membangun komunitas orang dewasa yang kuat, meluangkan waktu bagi karakter.

Dalam kehidupan moral di sekolah, tidak ada kesempatan yang lebih baik bagi para siswa untuk mengambil kesempatan dalam tanggung jawab otentik selain dari membantu menciptakan sekolah berkarakter. Para siswa harus dilibatkan sebagai rekkanan yang penting dalam tugas tersebut. Ketika para siswa berada dalam peranan kepemimpinan yang jelas, dan ketika semua siswa memiliki suara dan patokan dalam usaha pendidikan karakter, orang dewasa akan menjadi jauh lebih efektif dalam mendorong karakter baik dari pada yang dapat mereka lakukan sendiri.

c. Beberapa cara yang dapat dilakukan untuk melibatkan siswa dalam menciptakan sekolah yang berkarakter yaitu: melibatkan para siswa dalam merencanakan dan melaksanakan program pendidikan karakter, menggunakan pertemuan kelaas untuk memberikan anak-anak suara dan tanggung jawab, melibatkan para siswa dalam pemerintahan siswa partisipatoris di tingkat sekolah, memberikan kesempatan informal bagi masukan siswa, menantang para siswa untuk memimpin kampanye di sekolah, membentuk system mentoring, membentuk klub atau komite karakter dan menghargai kepemimpinan siswa 


\section{B. Saran}

a. Untuk membangun sebuah karakter di sekolah dibutuhkan Kegiatan pembelajaran, pengembangan budaya sekolah dan pusat kegiatan belajar, kegiatan ko-kurikuler dan atau kegiatan ekstrakurikuler dan kegiatan keseharian dirumah dan masyarakat.

b. Diharapkan dengan diterapkannya pendidikan karakter di SD dapat membentuk pribadi siswa yang unggul dalam berperilaku dan memiliki kepribadian yang sesuai dengan moral-moral pancasila dan agama. Untuk itu penerapan pendidikan karakter di SD sangat diperlukan, sehingga kita dapat menjadi orang yang bermoral dan berpancasila. Kemudian dengan adanya makalah ini diharapkan pembeca dapat menerapkannya dan mampu membangun sekolah yang berkarkter.

c. Dari segi penyusunan makalah ini, penulis juga meminta maaf apabila ada kata atau kalimat yang kurang berkenan, kami sangat mengharapkan saran dan kritik yang membangun dari para pembaca untuk perbaikan kedepannya. 


\section{DAFTAR PUSTAKA}

Aziz, A., \& Saihu, S. (2019). Interpretasi Humanistik Kebahasaan: Upaya Kontekstualisasi Kaidah Bahasa Arab. Arabiyatuna: Jurnal Bahasa Arab, 3(2), 299-214

Chaeles Elbot, David Fulton, and Barbara Evans. 2013. Educating for Character in the

Scool)

Denver Public School: An Implemnmtion Manual (Denver: Denver Public

Dirman, Juarsih Cicih. 2014. Karakteristik Peserta Didik (Dalam Rangka

Implementasi Standar Proses Pendidikan Siswa). Jakarta: PT. Rineka

Cipta.

https://afidburhanuddin.wordpress.com/pengembangan-sekolah-berkarakter/

diakses pada tanggal 01 November 2019 pukul 14.21WIB

Lickona ,Thomas. 2013. Character Matters. Jakarta: PT Bumi Aksara.

Mubin, F. (2019). TAFSIR EMANSIPATORIS: PEMBUMIAN METODOLOGI TAFSIR PEMBEBASAN. Mumtaz: Jurnal Studi Al-Quran dan Keislaman, 3(1), 131-151.

Mubin, F. KEADILAN DALAM GENDER: KAJIAN KEPEMIMPINAN WANITA DALAM ISLAM1,

Mubin, F. MODEL-MODEL PEMBELAJARAN BERBASIS MADRASAH DAN KEGIATAN LAIN YANG DIPERLUKAN DI DALAMNYA (FAKTOR PENDUKUNGNYA).

Ronaldo, R., Zulfikar, A., Saihu, Ismail, \& Wekke, I. S. (2020). International relations of the asia pacific in the age of trump. Journal of Environmental Treatment Techniques, 8(1), 244-246.

Şahin, C. RELIGIA.

Saihu, Aziz, A., Mubin, F., \& Sarnoto, A. Z. (2020). Design of islamic education based on local wisdom (An analysis of social learning theories in forming character through ngejot tradition in bali). International Journal of Advanced Science and Technology, 29(6), 1278-1293.

Saihu, M. (2019). Urgensi 'Urf dalam Tradisi Male dan Relevansinya dalam Dakwah Islam di Jembrana-Bali. Jurnal Bimas Islam, 12(1), 173-201.

Saihu, M. (2019). Merawat Pluralisme Merawat Indonesia (Potret Pendidikan Pluralisme Agama Di Jembrana-Bali). Deepublish.

Saihu, M. M., \& Aziz, A. (2020). Implementasi Metode Pendidikan Pluralisme Dalam Mata Pelajaran Pendidikan Agama Islam. Belajea; Jurnal Pendidikan Islam, 5(1), 131-150.

Saihu, S. (2019). IMPLEMENTASI MANAJEMEN BALANCED SCORECARD DI PONDOK PESANTREN JAM'IYYAH ISLAMIYYAH TANGERANG SELATAN. Mumtaz: Jurnal Studi Al-Quran dan Keislaman, 3(1), 1-22.

Saihu, S. (2019). KOMUNIKASI PENDIDIK TERHADAP ANAK BERKEBUTUHAN KHUSUS DI SEKOLAH KHUSUS ASY-SYIFA LARANGAN. Andragogi: Jurnal Pendidikan Islam dan Manajemen Pendidikan Islam, 1(3), 418-440.

Saihu, S. (2019). KONSEP MANUSIA DAN IMPLEMENTASINYA DALAM PERUMUSAN TUJUAN PENDIDIKAN ISLAM MENURUT 
MURTADHA MUTHAHHARI. Andragogi: Jurnal Pendidikan Islam dan Manajemen Pendidikan Islam, 1(2), 197-217.

Saihu, S. (2019). PENDIDIKAN KARAKTER BERBASIS KEARIFAN LOKAL (STUDI DI JEMBRANA BALI). Edukasi Islami: Jurnal Pendidikan Islam, 8(01), 69-90.

Saihu, S. (2019). Pendidikan Pluralisme Agama: Kajian tentang Integrasi Budaya dan Agama dalam Menyelesaikan Konflik Sosial Kontemporer. Jurnal Indo-Islamika, 9(1), 67-90,

Saihu, S. (2019). RINTISAN PERADABAN PROFETIK UMAT MANUSIA MELALUI PERISTIWA TURUNNYA ADAM AS KE-DUNIA. Mumtaz: Jurnal Studi Al-Quran dan Keislaman, 3(2), 268-279,

Saihu, S. (2020). ETIKA MENUNTUT ILMU MENURUT KITAB TA'LIM MUTA'ALIM. Al Amin: Jurnal Kajian Ilmu dan Budaya Islam, 3(1), 99112.

Saihu, S. (2020). KONSEP PEMBAHARUAN PENDIDIKAN ISLAM MENURUT FAZLURRAHMAN. Andragogi: Jurnal Pendidikan Islam dan Manajemen Pendidikan Islam, 2(1), 82-95.

Saihu, S. (2020). Pendidikan sosial yang terkandung dalam Surat At-Taubah Ayat 71-72. Edukasi Islami: Jurnal Pendidikan Islam, 9(01), 127-148.

Saihu, S. (2020). The Effect of Using Talking Stick Learning Model on Student Learning Outcomes in Islamic Primary School of Jamiatul Khair, Ciledug Tangerang. Tarbawi: Jurnal Keilmuan Manajemen Pendidikan, 6(01), 6168.

Saihu, S., \& Mailana, A. (2019). Teori pendidikan behavioristik pembentukan karakter masyarakat muslim dalam tradisi Ngejot di Bali. Ta'dibuna: Jurnal Pendidikan Islam, 8(2), 163-176.

Saihu, S., \& Marsiti, M. (2019). PENDIDIKAN KARAKTER DALAM UPAYA MENANGKAL RADIKALISME DI SMA NEGERI 3 KOTA DEPOK, JAWA BARAT. Andragogi: Jurnal Pendidikan Islam dan Manajemen Pendidikan Islam, 1(1), 23-54.

Saihu, S., \& Rohman, B. (2019). PEMBENTUKAN KARAKTER MELALUI MODEL PENDIDIKAN TRANSFROMATIFE LEARNING PADA SANTRI DI PONDOK PESANTREN NURUL IKHLAS BALI. Edukasi Islami: Jurnal Pendidikan Islam, 8(02), 435-452.

Saihu, S., \& Taufik, T. (2019). PERLINDUNGAN HUKUM BAGI GURU. $A l$ Amin: Jurnal Kajian Ilmu dan Budaya Islam, 2(2), 105-116. 